\title{
Listening Anxiety and Its Relationship with Listening Strategy Use and Listening Comprehension among Iranian IELTS Learners
}

\author{
Mona Mohammadi Golchi ${ }^{1}$ \\ ${ }^{1}$ Department of English Language, Islamic Azad University, Shiraz Branch, Shiraz, Iran \\ Correspondence: Mona Mohammadi Golchi, Department of English Language, Islamic Azad University, Shiraz \\ Branch, Shiraz, Iran. E-mail: monamohammadigolchi@yahoo.com
}

Received: May 14, 2012 Accepted: June 25, 2012 Online Published: July 25, 2012

doi:10.5539/ijel.v2n4p115

URL: http://dx.doi.org/10.5539/ijel.v2n4p115

\begin{abstract}
This study aimed at investigating listening anxiety and its relationship with listening strategy use and listening comprehension among Iranian IELTS learners. Sixty-three IELTS learners from two language institutes in Shiraz were selected for this study. To collect the data, four instruments were used: a Background Questionnaire developed by Lee (1997), a Listening Anxiety Questionnaire developed by Kim (2000), Lee's (1997) Listening Comprehension Strategy Questionnaire and an IELTS listening test. The results revealed that listening anxiety had negative correlation with listening comprehension and listening strategy use. Moreover, the findings showed that low anxious learners used metacognitive strategies more than did high anxious learners. In relation to cognitive and social/affective strategies, the two groups did not differ significantly. Low anxious learners also performed better in the listening comprehension test. Regarding learner characteristics, it was revealed that female learners were more anxious than male learners. Years of studying English also had a significant negative effect on IELTS learners' anxiety.
\end{abstract}

Keywords: listening anxiety, listening strategy use, listening comprehension, IELTS learner

\section{Introduction}

For some time, educators have recognized the existence of foreign language anxiety and its potential for significant interference with language learning and production. In 1986, Horwitz, Horwitz, and Cope defined FL anxiety as "a distinct complex of self-perceptions, beliefs, feelings, and behaviors related to classroom language learning arising from the uniqueness of the language learning process" (p. 128).

In fact, it is widely accepted that anxiety plays a crucial role while learning a foreign language. The impact of such an emotional arousal in language learning has long been considered in language classroom. Much of the past studies have been conducted on the aspect of anxiety associated with oral production in L2; however, recently interest has been extended to cover all language skills (Kimura, 2008). One of these skills is listening.

During listening process, different factors may cause uneasiness and tension for language learners and result in poor listening. Young (1992) stated that poor listening ability results from many factors, such as insufficient emphasis on listening, immature teaching methodologies, ineffective listening strategies, and students' lack of vocabulary, but the increasingly important one is anxiety. It plays a very important role because the anticipation of foreign language use in receiving information can provoke anxiety.

According to Scarcella and Oxford (1992), listening anxiety occurs when students face a task they feel is too difficult or unfamiliar. Young (1992) also stated that listening comprehension is highly anxiety-provoking if the discourse is incomprehensible. Learners may feel anxious while listening in the target language due to some difficulties associated with FL listening. Generally, as defined by Oxford (1993) listening is a complex, problem-solving skill and it is more than just perception of the sounds. Listening includes comprehension of meaning-bearing words, phrases, clauses, sentences and connected discourse. It is usually a hard skill to master in one's own language, let alone in another language.

Besides, such difficulties may be increased during international exams. In relation to listening section of IELTS, Rasti (2009) stated that most IELTS candidates find listening as one of the most difficult sections of IELTS due to the fact that it is both fast and confusing. Moreover, perhaps the biggest problem that candidates have with the 
IELTS academic listening test is that the listening recording is only played once. Therefore, they fear from losing some parts while listening.

In this respect, because listening is a challenging skill for foreign language learners in general and causes difficulty, developing effective listening strategies may help to overcome many problems related to target language listening. These strategies are the steps taken by learners to help them acquire, store, retrieve, and use information (O’Malley, Chamot, \& Küpper, 1989). Carefully designed listening strategy use can enhance the performance of the learners and help promote learner autonomy (Mendelsohn, 1994).

\section{Objectives of the Study}

This study intends to investigate whether FL listening anxiety is related to listening strategies used by Iranian IELTS learners, and whether this anxiety affects students' listening comprehension. A major goal is to determine whether listening anxiety and listening strategy use are separate phenomena in the IELTS learners' language classroom. The secondary aim of this study is to examine the relationship between listening anxiety and listening comprehension and to evaluate this anxiety across two learner characteristics: gender and years of studying English.

\section{Literature Review}

\subsection{Listening Anxiety}

While learning a foreign language, listening becomes more important as learners need to understand what is said to them for successful communication. Rivers (1981) stated that the necessity of developing listening skill for a FL learner as aural comprehension is the essential element in an act of communication. However, this skill is usually anxiety provoking. Christenberry (2003) underlined the problematic nature of listening and stressed that it is an incredibly difficult area to teach properly; thus, it is likely to cause anxiety. Furthermore, Vogely (1999) clearly emphasized that one of the most ignored but potentially one of the most debilitating type of anxiety is the anxiety accompanying listening comprehension. MacIntyre (1995) believed that listeners in L2 worry about misunderstanding or non-understanding, and they fear embarrassing outcomes. Chastain (1979) also stated that since listening is a complex skill, students have the fear of understanding the message and interpreting it correctly.

With regard to the cause of listening anxiety, Gonen (2009) stated that learners may feel anxious while listening in the target language due to many factors such as the authenticity of the listening text, incomprehensibility of the listening material and some external environmental factors like noise and inaudibility. According to Dunkel (1991), why many students complain about the difficulties of listening in FL may also depend on feelings of inadequacies or lack of confidence.

Other variables were identified by Vogely (1998), who looked at sources of listening anxiety among learners of Spanish at an American university, as reported by the students themselves. Half of their responses focused on the characteristics of the input (nature of the speech, level of difficulty, lack of clarity, lack of visual support, and lack of repetition) as being a major source of anxiety.

\subsection{Studies Conducted on Listening Anxiety}

Different studies have been conducted on listening anxiety in foreign language context. For example, in 2000, Kim studied the foreign language listening anxiety. One of the main findings of her study was the two-factor solution of her factor analysis of the foreign language listening anxiety scale: tension and worry over English listening and lack of confidence in listening, respectively. She also found a moderate association between listening anxiety and listening proficiency and demonstrated the somewhat obvious case that listening anxiety interferes with foreign language listening. Chang (2008a) also conducted a study to investigate college students' listening anxiety in learning English in a classroom context. The result indicated that participants showed moderately high intensity of anxiety in listening to spoken English, but were more anxious in testing than in general situations.

In 2007, Legac conducted a study to examine the foreign language anxiety and listening skill in Croatian monolingual and bilingual students of EFL. The result indicated that bilingual students experienced a considerably lower intensity of listening anxiety than monolingual students.

With respect to using some strategies to reduce listening anxiety, Chang (2008b) investigated the effect of four forms of listening support (pre-teaching of content and vocabulary, question preview, and repeated input) on the anxiety levels of college students in Taiwan. The result indicated that prior to the test, the test takers were uniformly anxious but afterwards, there were significant differences in anxiety according to type of support and level of proficiency. Ko (2010) explored the impact of pedagogical agents in computer-based listening 
instruction on EFL students' listening anxiety levels and listening comprehension skills. Results showed that there were no statistical differences in listening anxiety levels and listening comprehension skills between students who worked with the agent and students who worked without the agent. Gonen (2009) conducted a study to investigate the listening strategy and listening anxiety of sixty intermediate English proficiency students. The results revealed that when there is an increase in FL listening anxiety of the students, FL listening strategy use decreases.

These studies also support the findings of the recent studies conducted on the relationship between general classroom anxiety and strategy use. For example, Sioson (2011) and Lu and Liu (2011) found a negative correlation between strategy use and anxiety level.

Some other studies also considered the relationship between listening anxiety and gender. For example, Elkhafaifi (2005), Ko (2010) and Campbel (1999) found no significant difference between male and female learners in their listening anxiety.

Moreover, some studies investigated the relationship between listening anxiety and listening proficiency. Aneiro (1989) found that the apprehension of her Puerto Rican college students was most affected by their level of listening proficiency, followed by the amount of exposure to the foreign language and their general language competence. Elkhafaifi (2005), Mills, Pajares and Herron (2006) and Wang (2010) have also obtained evidence that learners' anxiety varies according to their level of ability in foreign language listening.

Chang (2010) examined the second language listening anxiety before and after one year intervention in extensive listening compared to standard foreign language instruction. The result indicated that extensive listening group improved more compared to the formal instruction group in listening competence.

Kimura (2011) also used a self-presentational framework to investigate second language listening anxiety among university students learning English in Japan and demonstrated that L2 listening involved social concerns that were specific to L2 settings. The result showed that L2 listening anxiety was specific to L2 situations and linked to L2 proficiency.

\subsection{Listening Comprehension Strategies}

In order to understand the meaning of listening strategies, at first, it is better to know the meaning of language learning strategies. Language learning strategies are "the techniques or devices that a learner may use to acquire knowledge" (Rubin, 1975, p. 43). Oxford and Crookall (1989) stated that language learning strategies are steps taken by learner to enhance the acquisition, storage and retention.

"Listening strategies refer to skills or methods for listeners to directly or indirectly achieve the purpose of listening comprehension of the spoken input" (Ho, 2006, p. 25). According to Gonen(2009), "As for listening, employment of listening strategy use is of crucial importance due to the online processing that takes place during listening. That is, learners have to decode the message, understand and interpret it in the course of listening" (p. 45).

Such strategies are divided into three main groups. O'Malley and Chamot (1990) and Vandergrift (1997) believed that listeners use metacognitive, cognitive and socio-affective strategies to facilitate comprehension and to make their learning more effective. Metacognitive strategies are important because they oversee, regulate or direct the language learning process. Cognitive strategies manipulate the material to be learned or apply a specific technique to a listening task. Socio-affective strategies describe the techniques listeners use to collaborate with others, to verify understanding and to lower anxiety.

In relation to metacognitve strategies, Vandergrift (1999) stated that metacognitive strategy is a kind of self-regulated learning. It includes the attempt to plan, check, monitor, select, revise, and evaluate, etc. It can be discussed through pre-listening planning strategies, while-listening monitoring strategies, and post-listening evaluation strategies.

Cognitive strategies are problem-solving that learners employ to manipulate their learning tasks and facilitate acquisition of knowledge or skills (Derry \& Murphy, 1986). Examples of cognitive strategies in the field of listening include predicting, inferencing, elaborating, and visualizing. Moreover, cognitive strategies are related to comprehending and storing input in working memory or long-term memory for later retrieval. They are investigated from the aspects of bottom-up strategies and top-down strategies.

For social/affective strategies, Vandergrift (2003) defined the strategies as the techniques listeners use to collaborate with others, to verify understanding or to lower anxiety. Habte-Gabr (2006) believed that social/affective strategies are those which are non-academic in nature and involve stimulating learning through 
establishing a level of empathy between the instructor and student. They consist of factors such as emotions and attitudes. It was essential for listeners to know how to reduce the anxiety, feel confident in doing listening tasks, and promote personal motivation in improving listening competence (Vandergrift, 1997).

\subsection{Studies Conducted on Listening Strategy Use}

Different studies have been conducted on listening strategies, for example, Fujita (1984) investigated the listening strategies of Japanese beginning college students. He found that the predominant strategies used by participants were translation and note taking. In 2002, Goh conducted a study to examine a group of Chinese ESL learners' listening strategies and the tactics that operationalized these strategies. It was found that although the participants used many similar strategies, the higher ability listeners demonstrated more effective use of both cognitive and metacognitive tactics.

In Vandergrift's (2003) investigation, which aimed to examine the relationship between listening proficiency and listening strategy use, 36 junior high school students of French in Canada were recruited for listening strategy elicitations. It was found that the more proficient listeners employed metacognitive strategies more frequently than did the less proficient listeners, and the variations in this type of strategy use had a statistically significant relation across the listening ability.

Hsueh-Jui (2008) studied the interrelationship between learners' listening strategy use across listening ability, and learning style. He found that there was a statistically significant difference between the strategy use and the attainment levels. The findings also suggested that listening strategy use was significantly associated with learning styles.

Some studies were also conducted in Iran. For example, Ahmadi and Yamini (2003) aimed to explore the relationship between field-dependence/field-independence and the use of listening comprehension strategies. Their findings indicated that metacognitive, memory, cognitive and social strategies were significantly related to the cognitive style, whereas affective and compensatory strategies did not show a significant correlation. They also found that field-independent listeners used metacognitive, memory, and cognitive strategies more frequently than their field-dependent counterparts, but field-dependent students made more use of social strategies than field-independent students.

Recently, Bidabadi and Yamat (2010) conducted a study on the relationship between the listening strategies and learning style preference. The results indicated that the learners employed metacognitive listening strategies such as planning, direct attention and selective attention the most and in terms of learning style preferences they considered themselves as communicative learners. The Pearson Correlation analysis showed that there was a statistically significant association between learning style preferences and listening strategies employed by Iranian EFL freshman university students.

In brief, different studies have been conducted on listening anxiety and listening strategy use (Wang, 2010; Elkhafaifi, 2005; Fujita, 1984; Ahmadi \& Yamini, 2003; Bidabadi \& Yamat, 2010). However, these two phenomena were considered separately. Actually, the relationship between listening anxiety and listening strategy use was of little interest, especially in Iranian EFL context. Moreover, listening anxiety scales are still new in the field of foreign language education and listening anxiety is believed to be generally high among language learners (Kim \& Cha, 2010). Therefore, this study aims at filling the gap in the recent literature on listening anxiety and its relationship with listening strategy use and listening comprehension.

\section{Research Questions}

Specifically, this study addresses the following research questions:

1. Is there a correlation between Iranian IELTS learners' listening anxiety and listening strategy use?

2. Is there a correlation between Iranian IELTS learners' listening anxiety and listening comprehension?

3. Do students with high and low levels of listening anxiety differ in their listening strategy use?

4. Do students with high and low levels of listening anxiety differ in their listening comprehension?

5. Do IELTS learners' levels of listening anxiety differ across categories of gender and years of studying English? 


\section{Methodology}

\subsection{Participants}

Participants in this study consisted of 63 IELTS learners. They were all native speakers of Persian. They consisted of 29 males and 34 females. They attended IELTS listening and speaking preparation course in two language institutes in Shiraz. The sampling strategy for selection was convenient sampling.

\subsection{Instruments}

The first data collection instrument used in this study was a Background Questionnaire developed by Lee (1997) and cited in Ho (2006). It asked about students' name, gender, age and years of studying English. The second instrument was the Foreign Language Listening Anxiety Scale (FLLAS) developed by Kim (2000) and cited in Kilic (2007). The questionnaire consisted of 33 Likert-scale items. The response continuum was $1=$ Strongly Disagree, 2 = Disagree, 3 = Neither Agree nor Disagree, $4=$ Agree, $5=$ Strongly Agree. Kim (2000) used factor analysis, internal consistency and test-retest reliability for this instrument. The result of internal consistency estimated for reliability was 0.93 and test-retest reliability was 0.84 (Kilic, 2007; Kimura, 2008). In this study, the internal consistency estimated for reliability of these 33 items was $\alpha=0.84$.

The third instrument was a sample of IELTS listening test. It consisted of 40 items divided into 4 parts. This sample was administered to obtain IELTS learners' level of listening comprehension. The last instrument was the Listening Strategy Use Questionnaire developed by Lee (1997) and modified by Ho (2006). The questionnaire was also modified by the researcher and some more strategies were added to it based on Vandergrift's (1997, 2003) cognitive and metacognitve listening strategy classification and O'malley and Chamot's (1990) language learning strategy. The scale consisted of 39 items divided into 3 categories of metacognitive, cognitive and social/affective. The internal consistency estimated for reliability of these 39 items was 0.92. The questionnaire is presented in Appendix.

Classification of 39 Strategies in the English Listening Comprehension Strategy Scale:

$\begin{array}{ll}\checkmark & \text { Metacognitive strategies } \\ & \text { Pre-listening planning strategies } \\ & \text { While-listening monitoring strategies } \\ & \text { Post-listening evaluation strategies } \\ & \text { Cognitive strategies } \\ & \text { Cognitive formal practicing strategies } \\ & \text { Cognitive translation } \\ & \text { Cognitive bottom-up strategies } \\ & \text { Cognitive top-down strategies } \\ & \text { Social/affective strategies }\end{array}$

Social strategies

Affective strategies

\subsection{Data Collection Procedure}

In this study, after obtaining the IELTS teachers' permission for conducting the research, the background questionnaire and anxiety questionnaire were distributed. The next session, listening comprehension test was administered. The time for administration was about 30 minutes. Finally, listening strategy use questionnaire was distributed. Since giving all questionnaires in one session might make the students tired and bored and affect their answers, the questionnaires were distributed in two different sessions.

\section{Data Analysis}

\subsection{Relationship between Listening Anxiety and Listening Strategy Use}

Table 1 shows the relationship between listening anxiety and listening strategy use. Pearson $r$ indicates a negative correlation between listening anxiety and listening strategy use with $r=-.32$ and $p<.05$. The negative correlation between the two variables indicates that the increase in learners' anxiety level is associated with the decrease in the strategies. 
Table 1. Relationship between listening anxiety and listening strategy use

\begin{tabular}{cccccc}
\hline & Mean & SD & $N$ & $r$ & Sig(2-tailed) \\
\hline Anxiety & 87.36 & 15.86 & 63 & $-.32 * *$ & .009 \\
Strategy & 116.84 & 24.85 & 63 & & \\
\hline
\end{tabular}

\subsection{Relationship between Listening Anxiety and Listening Comprehension}

As Table 2 shows, a significant negative correlation was found between listening anxiety and listening comprehension with $r=-.63$ and $p<.05$. Based on the result obtained, when IELTS learners' level of listening anxiety increased, their listening comprehension decreased.

Table 2. Relationship between listening anxiety and listening comprehension

\begin{tabular}{cccccc}
\hline & Mean & SD & $N$ & $r$ & Sig (2-tailed) \\
\hline Anxiety & 87.36 & 15.86 & 63 & $-.63^{* *}$ & .000 \\
Listening & 4.93 & 1.18 & 63 & & \\
\hline
\end{tabular}

\subsection{Difference between High and Low Anxious Learners’ Listening Strategies}

To determine the high and low anxious learners, the median score was calculated which was found to be 88 . Those who scored above the median were considered as highly anxious, and students whose scores fell below the median were put in the low group. The scores of the two groups of high and low anxious learners were compared using independent samples t-test.

Considering metacognitive strategies (Tables $3 \& 4$ ), the mean of low anxious learners is 34.67 and the mean of high anxious learners is 29.15 . The data below, $t_{61}=3.22(p<.05)$, show that the two groups differ significantly. However, they do not differ in the use of cognitive and social/affective strategies.

Tables 5 and 6 show the subcategories of strategy categories. Based on the data, $t_{61}=1.88(p>.05)$, there is no significant difference between high and low groups in the use of pre-listening planning strategies. However, these two groups differ in the use of while-listening monitoring strategies with $t_{61}=2.12(p<.05)$ and post-listening evaluation strategies with $t_{61}=3.12(p<.05)$. Considering cognitive strategies, two groups differ in the use of formal practicing strategies with $t_{55.60}=2.17(p<.05)$. However, they do not differ in the use of translation, top-down and bottom-up strategies. Moreover, in the use of social and affective strategies, high and low anxious learners do not differ significantly.

Table 3. Mean and Std. deviation of high and low anxious learners' listening strategy use

\begin{tabular}{lccccc}
\hline & & & & & Mean \\
& & & & Std. Deviation & $\begin{array}{c}\text { Std. Error } \\
\text { Mean }\end{array}$ \\
\hline Metacognitive & low & 31 & 34.67 & 6.61 & 1.18 \\
& high & 32 & 29.15 & 6.96 & 1.23 \\
Cognitive & low & 31 & 69.90 & 15.12 & 2.71 \\
& high & 32 & 64.28 & 19.63 & 3.47 \\
Social/affective & low & 31 & 18.54 & 4.75 & .85 \\
& high & 32 & 17.18 & 5.28 & .93 \\
\hline
\end{tabular}


Table 4. Independent sample t-test for high and low anxious learners' listening strategies use

\begin{tabular}{lccccccc}
\hline & \multicolumn{3}{c}{$\begin{array}{c}\text { Levene's Test for } \\
\text { Equality of Variances }\end{array}$} & \multicolumn{3}{c}{ t-test for Equality of Means } \\
\cline { 2 - 7 } & $F$ & Sig. & $t$ & $d f$ & $\begin{array}{c}\text { Sig. } \\
\text { (2-tailed) }\end{array}$ & Difference & Difference \\
\hline Metacognitive & .011 & .91 & 3.22 & 61 & .002 & 5.52 & 1.71 \\
Cognitive & 3.134 & .082 & 1.27 & 61 & .209 & 5.62 & 4.42 \\
Social/Affective & .740 & .393 & 1.07 & 61 & .288 & 1.36 & 1.26 \\
\hline
\end{tabular}

Table 5. Mean and Std. deviation of high and low anxious learners in the use of subcategories of strategy categories

\begin{tabular}{|c|c|c|c|c|c|}
\hline & Code & $N$ & Mean & $\begin{array}{c}\text { Std. } \\
\text { Deviation }\end{array}$ & $\begin{array}{c}\text { Std. } \\
\text { Error Mean }\end{array}$ \\
\hline \multirow[t]{2}{*}{ Planning } & low & 31 & 10.77 & 2.47 & .44 \\
\hline & high & 32 & 9.46 & 2.98 & .52 \\
\hline \multirow[t]{2}{*}{ Monitoring } & low & 31 & 10.35 & 2.36 & .42 \\
\hline & high & 32 & 9.06 & 2.47 & .43 \\
\hline \multirow[t]{2}{*}{ Evaluation } & low & 31 & 13.54 & 3.74 & .67 \\
\hline & high & 32 & 10.62 & 3.68 & .65 \\
\hline Formal & low & 31 & 11.48 & 3.40 & .61 \\
\hline Practicing & high & 32 & 9.18 & 4.86 & .85 \\
\hline \multirow[t]{2}{*}{ Translation } & low & 31 & 2.67 & 1.32 & .23 \\
\hline & high & 32 & 2.37 & 1.31 & .23 \\
\hline \multirow[t]{2}{*}{ Bottom up } & low & 31 & 11.51 & 2.42 & .43 \\
\hline & high & 32 & 10.28 & 3.23 & .57 \\
\hline \multirow[t]{2}{*}{ Top down } & low & 31 & 44.22 & 9.77 & 1.75 \\
\hline & high & 32 & 42.43 & 12.13 & 2.14 \\
\hline \multirow[t]{2}{*}{ Social } & low & 31 & 5.35 & 1.90 & .34 \\
\hline & high & 32 & 4.71 & 2.21 & .39 \\
\hline \multirow[t]{2}{*}{ Affective } & low & 31 & 13.19 & 3.40 & .61 \\
\hline & high & 32 & 12.46 & 3.65 & .64 \\
\hline
\end{tabular}


Table 6. Independent sample t-test for high and low anxious learners' use of subcategories of strategy categories

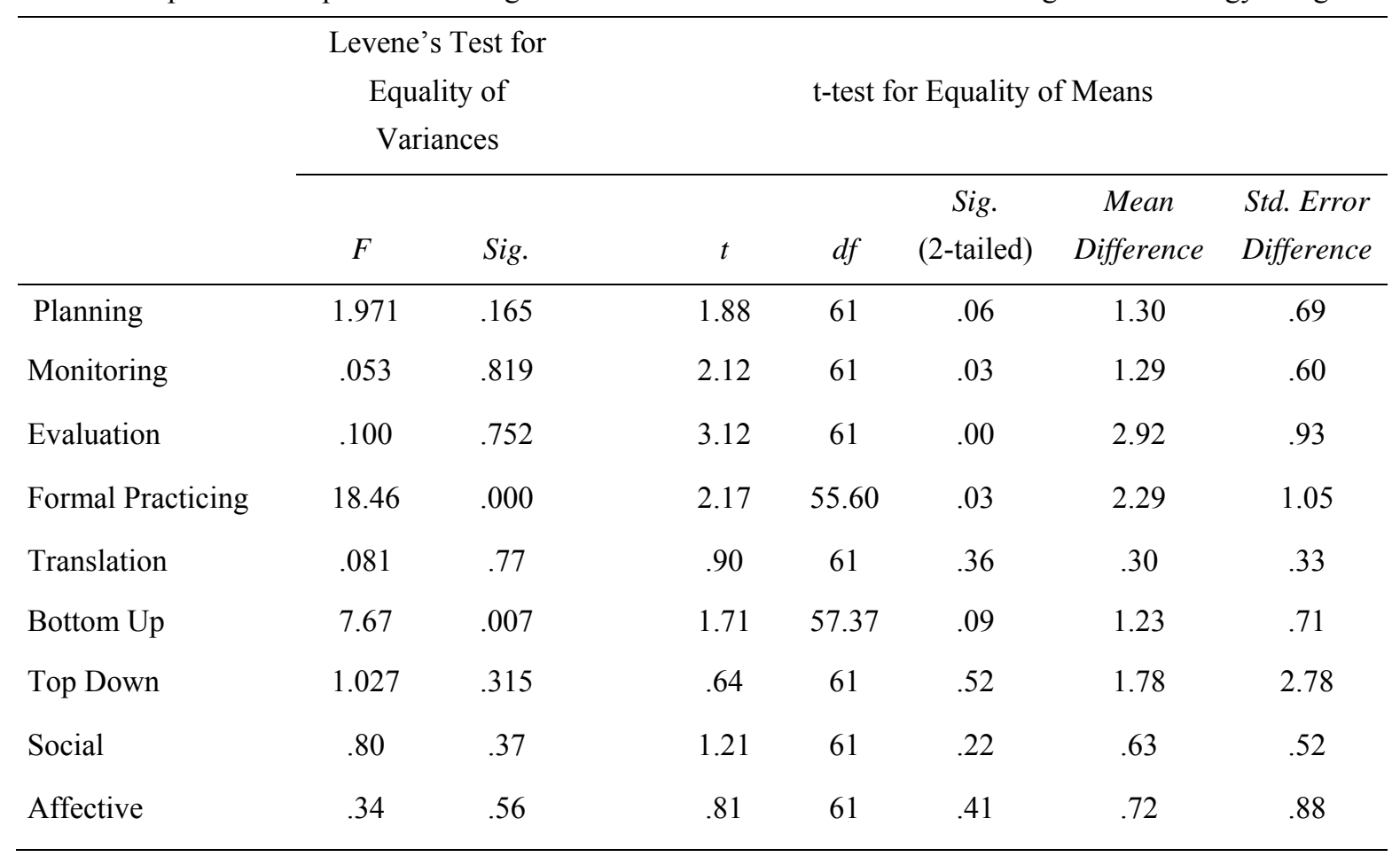

\subsection{Difference between High and Low Anxious Learners' Listening Comprehension}

Based on the data obtained (Table $7 \& 8$ ), the mean of low anxious learners is 5.48 and the mean of high anxious learners is 4.40 . Moreover, the data, $t_{53.92}=3.98(p<.05)$, show that the two groups differ significantly.

Table 7. Mean and Std. deviation of high and low anxious learners' listening comprehension

\begin{tabular}{cccccc}
\hline & code & $N$ & Mean & Std. Deviation & Std. Error Mean \\
\hline listening & low & 31 & 5.48 & 1.23 & .22 \\
& high & 32 & 4.40 & .87 & .15 \\
\hline
\end{tabular}

Table 8. Independent sample t-test for high and low anxious learners' listening comprehension

\begin{tabular}{cccccccc}
\hline & $\begin{array}{c}\text { Levene's Test for Equality } \\
\text { of Variances }\end{array}$ & \multicolumn{5}{c}{ t-test for Equality of Means } \\
\cline { 2 - 8 } & $F$ & Sig. & $t$ & $d f$ & Sig. (2-tailed) & $\begin{array}{c}\text { Mean } \\
\text { Difference }\end{array}$ & $\begin{array}{c}\text { Std. Error } \\
\text { Difference }\end{array}$ \\
\hline Listening & 5.059 & .028 & 3.98 & 53.92 & .000 & 1.07 & .27 \\
\hline
\end{tabular}

\subsection{Listening Anxiety across Gender and Years of Studying English}

For obtaining the IELTS learners' listening anxiety across gender and years of studying English, Two-Way ANOVA was calculated. As Table 9 shows, $(p<.05)$, there is a significant difference between male and female learners in their listening anxiety. In fact, female learners were more anxious than male learners.

Years of studying English were divided into four parts: one to three, four to six, seven to nine and ten to twelve years. As Table 9 displays, $(p<.05)$, significant differences were found between these groups in relation to anxiety. That is, years of studying English had significant positive effects on IELTS learners' listening anxiety.

Table 10 displays the Scheffe test for difference between the years of studying English. As can be seen, there are significant differences between the students with one to three years and students with seven to nine years and ten 
to twelve years of studying English. The students with one to three years of studying English had more anxiety in comparison to the other groups. However, the other groups did not differ significantly.

Table 9. Two way ANOVA for gender difference and years of studying English

\begin{tabular}{lccccc}
\hline \multicolumn{1}{c}{ Source } & $\begin{array}{c}\text { Type III Sum of } \\
\text { Squares }\end{array}$ & $d f$ & Mean Square & $F$ & Sig. \\
\hline Corrected Model & 5964.67 & 7 & 852.09 & 4.86 & .000 \\
Intercept & 347703.24 & 1 & 347703.24 & 1984.62 & .000 \\
gender & 2220.82 & 1 & 2220.82 & 12.67 & .001 \\
Years & 2348.75 & 3 & 782.92 & 4.46 & .007 \\
gender * years & 496.83 & 3 & 165.61 & .94 & .425 \\
Error & 9635.92 & 55 & 175.19 & & \\
Total & 496458.00 & 63 & & & \\
Corrected Total & 15600.60 & 62 & & & \\
\hline
\end{tabular}

Table 10. Scheffe test for difference between the years of studying English

\begin{tabular}{|c|c|c|c|c|}
\hline Years of Study & Years of Study & $\begin{array}{c}\text { Mean Difference } \\
(I-J)\end{array}$ & Std. Error & Sig. \\
\hline \multirow[t]{3}{*}{$1-3$} & $3-6$ & 10.55 & 4.16 & .105 \\
\hline & $7-9$ & $16.06^{*}$ & 4.99 & .022 \\
\hline & $10-12$ & $18.34^{*}$ & 5.45 & .016 \\
\hline \multirow[t]{3}{*}{$4-6$} & $1-3$ & -10.55 & 4.16 & .105 \\
\hline & $7-9$ & 5.51 & 4.64 & .705 \\
\hline & $10-12$ & 7.79 & 5.14 & .519 \\
\hline \multirow[t]{3}{*}{$7-9$} & $1-3$ & $-16.06^{*}$ & 4.99 & .022 \\
\hline & $4-6$ & -5.51 & 4.64 & .705 \\
\hline & $10-12$ & 2.27 & 5.83 & .985 \\
\hline \multirow[t]{3}{*}{$10-12$} & $1-3$ & $-18.3464^{*}$ & 5.45 & .016 \\
\hline & $4-6$ & -7.79 & 5.14 & .519 \\
\hline & $7-9$ & -2.27 & 5.83 & .985 \\
\hline
\end{tabular}

\section{Discussion and Conclusion}

This study aimed at investigating the relationship between IELTS learners' listening anxiety, their listening strategy use and listening comprehension. It also aimed at finding the listening anxiety of IELTS learners across learner characteristics. Based on the findings, the relationship between listening anxiety and listening strategy use showed a negative correlation. The findings are in line with the findings of the studies conducted by Chang (2008b) and Gonen (2009). Gonen (2009) found that when there is an increase in FL listening anxiety, FL listening strategy use decreases. With respect to the relationship between classroom anxiety and general strategy use, it also supports the findings of Sioson (2011) and Lu and Liu (2011). Sioson (2011) stated that "because LLSs are specific techniques that enable learners to cope and manage their learning, there might have been an increase in their self-confidence, thus lowering their anxiety" (p. 20). 
Based on the results obtained, there is a negative correlation between IELTS learners' listening anxiety and listening comprehension. When students' anxiety increases, their comprehension of listening tasks decreases. This finding is in line with the findings of Aneiro (1989), Elkhafaifi (2005), Mills, Pajares and Herron (2006), Chang (2010), Wang (2010) and Kimura (2011). These studies also revealed that learners' anxiety varies according to their level of ability in foreign language listening.

In this study, high and low anxious learners differed in the use of metcognitive strategies. Low anxious learners used more metacognitive strategies than did high anxious learners. However, these two groups did not differ in the use of cognitive and social/affective strategies. In terms of the relationship between anxiety and metacognitive strategies, Sioson (2011) stated that when students use more metacognitive strategies, they have less feelings of communication apprehension, fear, and general feelings of anxiety. This is probably because metacognitive strategies deal with goal setting, planning and monitoring of learning, which somehow lessen anxiety, thus, possibly making them more confident. However, in terms of two other groups of strategies, cognitive and social/affective, the two groups did not differ significantly. In relation to subcategories of metacognitive strategies, low anxious learners used while-listening monitoring and post-listening evaluation strategies more than did high anxious learners. Low anxious learners also used cognitive formal practicing strategies more than other cognitive strategies. However, these two groups did not differ in the use of social and affective strategies.

High and low anxious learners also differed in their listening comprehension. In fact, low anxious learners performed better in their listening comprehension tasks. Regarding the effect of gender on listening anxiety, the findings showed that female learners were more anxious than male learners. This finding is in contrast to the results reported by Ko (2010), Elkhafaifi (2005) and Campbell (1999) who found that gender had no effect on students listening anxiety. The findings also revealed that the students with one to three years of studying English were more anxious than the students with seven to nine and ten to twelve years of studying English. In fact, years of studying English had significant positive effect on listening anxiety.

The findings obtained from the present study may offer the following implications. As was already mentioned, listening anxiety may increase during international exams such as IELTS and TOEFL, because the listening section of these exams is only played once. Therefore, IELTS instructors can acquaint IELTS learners with the importance of listening strategies and possible methods to apply these strategies in order to reduce their listening anxiety and enhance their listening comprehension. Specifically, training students in using metacognitive strategies can be helpful in reducing IELTS learners' listening anxiety. Moreover, syllabus designers and IELTS materials developers can provide techniques, strategies and helpful hints in order to help learners reduce their anxiety and become more proficient listeners. Since these strategies are general in the area of listening skill, all advanced EFL learners can use them to reduce their listening anxiety and increase their comprehension.

\section{References}

Ahmadi, A., \& Yamini, M. (2003). Relationship between field dependence/independence and listening comprehension strategy use by female Iranian English majors. Retrieved from http://www.sid.ir/en/VEWSSID/J_pdf/874200318704.pdf

Aneiro, S. (1989). The influence of receiver apprehension in foreign language learners on listening comprehension among Puerto Rican college students. Unpublished doctoral dissertation. New York University, USA.

Bidabadi, S. F., \& Yamat, H. (2010). The relationship between listening strategies employed by Iranian EFL freshman university students and their learning style preferences. European Journal of Social Sciences, 16(3), 342-351.

Campbell, C. M. (1999). Language anxiety in men and women: Dealing with gender differences in the language classroom. In Dolly, J. Young (Ed.), Affect in foreign language and second language learning: A practical guide to creating a low anxiety classroom atmosphere (pp.191-215). Boston: McGraw-Hill College.

Chang, C. A. (2008a). Sources of listening anxiety in learning English as a foreign language. Perceptual and Motor Skills, 106, 21-34. http://dx.doi.org/10.2466/pms.106.1.21-34

Chang, C. A. (2008b). Reducing listening test anxiety through various forms of listening support. Retrieved from http://www.tesl-ej.org/ej45/a1abs.html

Chang, C. A. (2010). Second-language listening anxiety before and after a 1-yr. intervention in extensive listening compared with standard foreign language instruction. Perceptual and Motor Skills, 110(2), 355-365. http://dx.doi.org/10.2466/pms.110.2.355-365 
Chastain, K. D. (1979). Testing listening comprehension Tests. TESOL Quarterly, 13, 81-88. http://dx.doi.org/10.2307/3585978

Christenberry, B. (2003). Listening comprehension in the foreign language classroom. Retrieved from $\mathrm{http} / / /$ langlab.uta.edu/german/lana.rings/fall01 gradstudents/2001 paperchristenberry.htm

DeFilippis, D. A. (1980). A study of the listening strategies used by skillful and unskillful college French students in aural comprehension tasks. Doctoral dissertation. University of Pittsburgh, Pennsylvania, U.S.A.

Derry, J. J., \& Murphy, D. A. (1986). Designing systems to train learning ability: From theory to practice. Review of Educational Research, 56, 1-39.

Dunkel, P. (1991). Listening in the native and the second/foreign language: Toward an integration of research and practice. TESOL Quarterly, 25, 431-457. http://dx.doi.org/10.2307/3586979

Elkhafaifi, H. (2005). Listening comprehension and anxiety in the Arabic language classroom. The Modern Language Journal, 9, 206-220. http://dx.doi.org/10.1111/j.1540-4781.2005.00275.x

Fujita, J. (1984). An inquiry into the successful and unsuccessful listening strategies of students of college Japanese. Unpublished $\mathrm{PhD}$ dissertation. The Ohio State University, USA.

Goh, C. C. M. (2002). Exploring listening comprehension tactics and their interaction patterns. System, 30(2), 185-206. http://dx.doi.org/10.1016/S0346-251X(02)00004-0

Gonen, M. (2009). The relationship between FL listening anxiety and foreign language listening strategies: the case of Turkish EFL learners. Proceedings of the 5th WSEAS/IASME International Conference on Educational Technologies (EDUTE' 09).

Habte-Gabr, E. (2006). The Importance of socio-affective strategies in using EFL for teaching mainstream subjects. The Journal of Humanizing Language Teaching. Retrieved from http://www.hltmag.co.uk/sep06/sart02.htm\#C1I

Horwitz, E., Horwitz, M., \& Cope, J. A. (1986). Foreign language classroom anxiety. Modern Language Journal, 70, 125-132. http://dx.doi.org/10.1111/j.1540-4781.1986.tb05256.x

Ho, H. (2006). An investigation of listening strategy used among English major college students in Taiwan a case of Chaoyang University of Technology. A master thesis. Taiwan.

Hsueh-Jui, L. (2008). A study of the interrelationship between listening strategy use and listening proficiency levels, and learning style. Articles, 5, 84-104.

Kilic, M. (2007). The sources and relations of foreign language listening anxiety with respect to text type and learner variables: A case study at Gaziantep University. A master thesis. Retrieved from http://www.belgeler.com/blg/1g7d

Kim, E., \& Cha, W. (2010). Language learning anxiety, listening anxiety, and listening strategy: A case study of a college-level English listening class. ALAK 2010 International Conference.

Kimura, H. (2008). Foreign language listening anxiety: Its dimensionality and group differences. JALT Journal, 30,173-196.

Kimura, H. (2011). A self-presentational perspective on foreign language listening anxiety. Retrieved from http://gradworks.umi.com/34/77/3477769.html

Kim, J. H. (2000). Foreign language listening anxiety: A study of Korean students learning English. Unpublished doctoral dissertation. University of Texas, Austin.

Ko, Y. A. (2010). The effects of pedagogical agents on listening anxiety and listening comprehension in an English as a foreign Language context. Doctoral Dissertation. Utah State University.

Lee, H. M. (1997). A study of the listening comprehension strategies of junior college EFL students in Taiwan. Proceeding of the 14 Conferecne on English Teaching and Learning in Republic of China. Taipei: Crane.

Legac, V. (2007). Foreign-language anxiety and listening skill in Croatian monolingual and bilingual students of EFL. In J. Horváth, \& M. Nikolov (Eds.), UPRT 2007: Empirical studies in English applied linguistics (pp. 217-243). 
Lu, Z., \& Liu, M. (2011). Foreign language anxiety and strategy use: A study with Chinese undergraduate EFL learners. Journal of Language Teaching and Research, 2, 1298-1305. http://dx.doi.org/10.4304/jltr.2.6.1298-1305

MacIntyre, P. D. (1995). How does anxiety affect second language leaning? A reply to Sparks and Ganschow. Modern Language Journal, 79, 90-99. http://dx.doi.org/10.1111/j.1540-4781.1995.tb05418.x

Mendelsohn, D. J. (1994). Learning to listen: A strategy-based approach for the second-language learner. San Diego, CA: Dominie Press.

Mills, N., Pajares, F., \& Herron, C. (2006). A reevaluation of the role of anxiety: Self-efficacy, anxiety, and their relation to reading and listening proficiency. Foreign Language Annals, 39, 276-295. http://dx.doi.org/10.1111/j.1944-9720.2006.tb02266.x

O’Malley, J. M., Chamot, A. U., \& Küpper, L. (1989). Listening comprehension strategies in second language acquisition. Applied Linguistics, 10(4), 418-437. http://dx.doi.org/10.1093/applin/10.4.418

O’Malley, J. M., \& Chamot, A. U. (1990). Learning strategies in second language acquisition. Cambridge: Cambridge University Press.

Oxford, L. R. (1993). Research update on teaching L2 listening. System, 21(2), 205-211. http://dx.doi.org/10.1016/0346-251X(93)90042-F

Oxford, R. L., \& Crookal, D. (1989). Research on language learning strategies: methods, findings and instructional issues. Modern Language Journal, 43 , http://dx.doi.org/10.1111/j.1540-4781.1989.tb05321.x

Rasti, I. (2009). Iranian candidates' attitudes towards IELTS. Asian EFL Journal, 11, 110-155.

Rivers, V. M. (1981). Teaching foreign language skills. Chicago: The University of Chicago Press.

Rubin, J. (1975). What the good language learner can teach us. TESOL quarterly, 9, 41-51. http://dx.doi.org/10.2307/3586011

Scarcella, R. C., \& Oxford, R. L. (1992). The tapestry of language learning: The individual in the communicative classroom. Boston: Heinle \& Heinle.

Sioson, C. I. (2011). Language learning strategies, beliefs, and anxiety in academic speaking task. Philippine ESL Journal, 7, 3-27.

Vandergrift, L. (1997). The strategies of second language (French) listeners. Foreign Language Annals, 30(3), 387-409. http://dx.doi.org/10.1111/j.1944-9720.1997.tb02362.x

Vandergrift, L. (1999). Facilitating second language listening comprehension: acquiring successful strategies. ELT Journal, 53(3), 168-176. http://dx.doi.org/10.1093/elt/53.3.168

Vandergrift, L. (2003). Orchestrating strategy use: Toward a model of the skilled second language listener. Language Learning, 53(4), 463-496. http://dx.doi.org/10.1111/1467-9922.00232

Vogely, A. J. (1998). Listening comprehension anxiety: Students' reported sources and solutions. Foreign Language Annals, 31, 67-80. http://dx.doi.org/10.1111/j.1944-9720.1998.tb01333.x

Vogely, A. J. (1999). Addressing listening comprehension anxiety. In D. J. Young (Ed.), Affect in foreign language and second language learning. A practical guide to creating a low-anxiety atmosphere. Boston: McGraw-Hill.

Wang, S. (2010). An experimental study of Chinese English major students' listening anxiety of classroom learning activity at the university level. Journal of Language Teaching and Research, 1, 562-568. http://dx.doi.org/10.4304/j1tr.1.5.562-568

Young, D. J. (1992). Language anxiety from the foreign language specialist's perspective: Interactive with Krashen, Omaggio Hadley, Terrell, and Rubin. Foreign Language Annuals, 25, 157-172. http://dx.doi.org/10.1111/j.1944-9720.1992.tb00524.x 


\section{Appendix}

Appendix 1. Listening Comprehension Strategy Scale

Advanced organization

Direct attention

Selective attention

Self management

Self monitoring

refocusing

Self evaluation

Comprehension monitoring

Problem identification

Evaluation

Previewing

Resourcing

Translation

Deduction

Repetition

Segmentation

Note taking

Remarking the key idea

Listening for main Idea

Inferencing

Linguistic

inferencing

Extra linguistic inferencing

Between parts inferencing

Voice inferencing

Think in English

Imagery
1. Before listening, I clarify the objective of an anticipated listening task and/or propose strategies for handling it.

2. Before listening, I concentrate my mind on the listening task and don't pay attention to things that distract my attention.

3. Before listening, I scan the questions first, and then decide to listen for specific aspects of scripts.

4. While listening, I try to keep up with the speed.

5. While listening, I ask myself what I am listening to, or how much I have understood.

6. I am answer of my inattention and will make myself refocus on the material.

7. After listening, I self check my listening comprehension and try to correct my errors.

8. After listening, I look up dictionary to check my comprehension.

9. After listening, I reflect on my problems or difficulties, such as, the speech rate was too fast, or the linkage was hard to identify.

10. After listening, I use a checklist to evaluate my listening progress.

11. Before listening, I preview the lesson.

12. I use tools to understand the scripts, such as dictionary, grammar book, or encyclopedia.

13. I try to translate words or sentences into my own language.

14. I use linguistic clues to comprehend the scripts, such as prefixes and suffixes.

15. While listening, I repeat words or phrases softly or mentally.

16. I use pronunciation, intonation and pausing to part sentences.

17. While listening, I write down some ideas and keywords.

18. I remark the key points of the scripts by underlining or capitalizing.

19. I listen for main ideas first, then details.

20. I predict or make hypotheses on texts by titles and then verify my anticipation.

21. I guess the meaning of unfamiliar words using known words in the surrounding context.

22. I try to use background sounds and noise and relationship between speakers to guess the meaning of unknown words.

23. I try to use information beyond the sentence level to guess the meaning of unknown words.

24. I try to use the speakers' tone of voice, pause and intonation to guess the meaning of unknown words

25. I try to think in English.

26. I use mental or actual pictures to help me comprehend scripts. 
Personal elaboration

World elaboration

Academic elaboration

Questioning

Elaboration

Creative elaboration

Summarization

Transfer

Question for

clarification

Cooperation

Empathy

Lowering anxiety

Self reinforcement

Sharing
27. I relate new information to my personal experience or knowledge.

28. I try to relate new knowledge to the knowledge or experience I gain from the world

29. I try to relate the new knowledge to the knowledge or information I gain in academic context (textbook from university or school)

30. I try to use the combination of questions and world knowledge to understand the meaning.

31. I try to use my creativity such as making a story to help me comprehend the script.

32. I try to make a written or mental short summary of what I have listened to comprehend the meaning.

33. I try to use knowledge of my own language to facilitate listening in another (example: cognates)

34. I ask speakers for repetition or paraphrasing to clarify comprehension.

35. When I encounter unclear items in class, I will discuss with my classmates to clarify comprehension.

36. I try to care for the speaker's thought and feeling.

37. I am not anxious and keep calm while listening.

38. I encourage myself through positive self-talk.

39. I discuss my experiences or feeling of listening with classmates. 